\title{
Subcutaneous Adipose Tissue and Lipids in Blood in Growth Hormone Deficiency before and after Treatment with Human Growth Hormone
}

\author{
FERNAND BONNET, ${ }^{(47)}$ MAGDA VANDERSCHUEREN-LODEWEYCKX, ROGER EECKELS, \\ AND PAUL MALVAUX \\ Departments of Pediatrics, Université de l'Etat de Liège, Katholieke Universiteit, Leuven, and \\ Université Catholique de Louvain, Louvain, Belgium
}

\section{Extract}

This study was undertaken to evaluate adipose cell size and number and subcutaneous fat and blood lipids composition in hypopituitary patients before and during treatment with human growth hormone (HGH). The investigations were performed in 14 prepubertal children 6-17 $11 / 12$ years of age, with idiopathic hypopituitarism. Human growth hormone was administered successfully to 6 of these 14 patients for at least 1 year.

Before HGH treatment there was a significant reduction of adipose tissue cell number according to chronologic age and to skeletal age. The average adipose cell size was significantly larger than normal. A significant correlation between subcutaneous adipose cell mean weight and tricipital and subscapular skinfold thickness, similar to that observed in normal children, was observed. The distribution of fatty acids in the subcutaneous fat and in the blood lipid composition was normal.

During the 1 st and 2nd year of HGH treatment, the total number of adipose cells increased rapidly. There was also a highly significant reduction of the average adipose cell size after the 1st year. A significant reduction of the fatty acids unsaturated fraction was observed after the 1st year without further changes after the 2nd year of treatment. The blood lipid composition did not change significantly after either 1 or 2 years of HGH treatment.

\section{Speculation}

The striking increase in total number of adipose cells observed during $\mathrm{HGH}$ administration in hypopituitary patients tends to prove that the adifose tissue organogenesis is not limited to a finite period ending after the 1 st year of life.

The modifications in composition of adipose tissue triglycerides induced by long term treatment with HGH would mean that the several components of the fatty acid pool are differentially liberated.

The importance of growth hormone $(\mathrm{GH})$ for the multiplication of muscle, cartilage, or liver cells has been well established both in man and in animals (9). Brook (7) has shown that at the end of intrauterine growth and during the first year of life,
GH is necessary for the replication of subcutaneous adipose cells. It has also been shown that successful treatment of hypopituitary patients with HGH reduces skinfold thickness during the first 3 months. Thereafter, skinfold thickness increases progressively and returns to pretreatment values which are attained after 4-5 years of therapy $(1,26,27,32$, $33)$.

Because modifications of the adipocytes must explain the changes in skinfold thickness observed during treatment with HGH, this study was urdertaken to evaluate adipose cell size and number and subcutaneous fat and blood lipids composition in hypopituitary patiemts: before and during treatment with HGH.

\section{MATERIALS AND METHODS}

\section{SUBJECTS}

The investigations were performed in 14 prepubertal children, 10 boys and 4 girls, 6-17 $11 / 12$ years of age, with idiopathic hypopituitarism. Clinical data are summarized in Table 1. Group I contains the hypopituitary subjects who have been treated subsequently with $\mathrm{HGH}$, whereas group II consists of patients untreated so far. The standards used for height, weight, and height velocity were those of Tanner $e t a l$. (34) and standard deviation scores (SD) were calculated according to Tanner et al. (33). It should be remembered that in older patients, as in case $M P$, the SD can give a false figure because it must be compared with adolescent spurt velocities in the standards (33). Bone age was determined by comparison with the standards of Greulich and Pyle (16).

In all cases, GH deficiency was documented by the absence of $\mathrm{GH}$ release during at least two of the following tests: intravenous insulin $(0.1 \mathrm{IU} / \mathrm{kg}$ of body wieght) (29), arginine infusion $(0.5 \mathrm{~g} / \mathrm{kg}$ body weight for $30 \mathrm{~min})$ (24), and intramuscular gluczgon $(0.1 \mathrm{mg} / \mathrm{kg}$ body wt) (36). Associated hormonal deficiencies were investigated by measuring serum PBI and serum thyroxine; thyroid-stimulating hormone release was studied after intravenous injection of $200 \mu \mathrm{g}$ synthetic thyrotropin-releasing hormone $(23,40)$; follicle-stimulating and luteinizing hormone release was studied after intravenous injection of $25 \mu \mathrm{g}$ synthetic luteinizing hormone-releasing hormone $(19,35,40)$ except in cases $D N, M P$, and $B V$ in whom these data are not yet available; pituitary adrenocortico- 
tropic hormone reserve was evaluated by the diurnal variation of cortisol in plasma, the response to insulin, and the metyrapone test (39). One patient $(H B)$ who had been treated previously with androgens needed cortisone replacement therapy. Cases $R B$ and $H B$ are siblings and were subjects of another report (18). Case $P D$ is a hypopituitary child of very tall parents (31). Seven patients received appropriate individually adapted amounts of thyroid extract to remain euthyroid. The tests were performed when the subjects were euthyroid for at least 6 months.

HGH prepared according to the method of Raben (28) was administered successfully to 6 of these 14 patients. Cases $A N$, $E G$, and $R R$ received $5 \mathrm{mg}$ twice a week for 2 years. In the three other patients $(M C, D N$, and $M P) 2.5 \mathrm{mg}$ twice a week was administered for 1 year. The conversion of milligrams into international units is unknown. Table 2 represents some of the effects of $\mathrm{HGH}$ treatment in these cases.
LABORATORY METHODS

After having obtained informed consent from the patient's parents, subcutaneous adipose tissue samples were taken by biopsy from the left subscapular area (11) and blood was withdrawn for gas-liquid chromatography analysis of serum lipids. An adipose tissue fragment weighing 4-15 $\mathrm{mg}$ was treated by osmium tetroxide according to the method of Hirsch and Gallian (17). The diameter of 200 adipocytes was measured microscopically. The variance of the cell diameter was calculated in each case. Mean cell volume was determined according to the method of Goldrick (15); mean fat cell weight was obtained assuming that the density of adipocyte triglycerides equals that of triolein (0.915) (17).

Triglycerides extracted according to the method of Folch et al. (14) from a second adipose tissue shred were submitted to an intermethylation reaction as described previously $(3,4)$.

Table 1. Hypopituitary patients: clinical data ${ }^{1}$

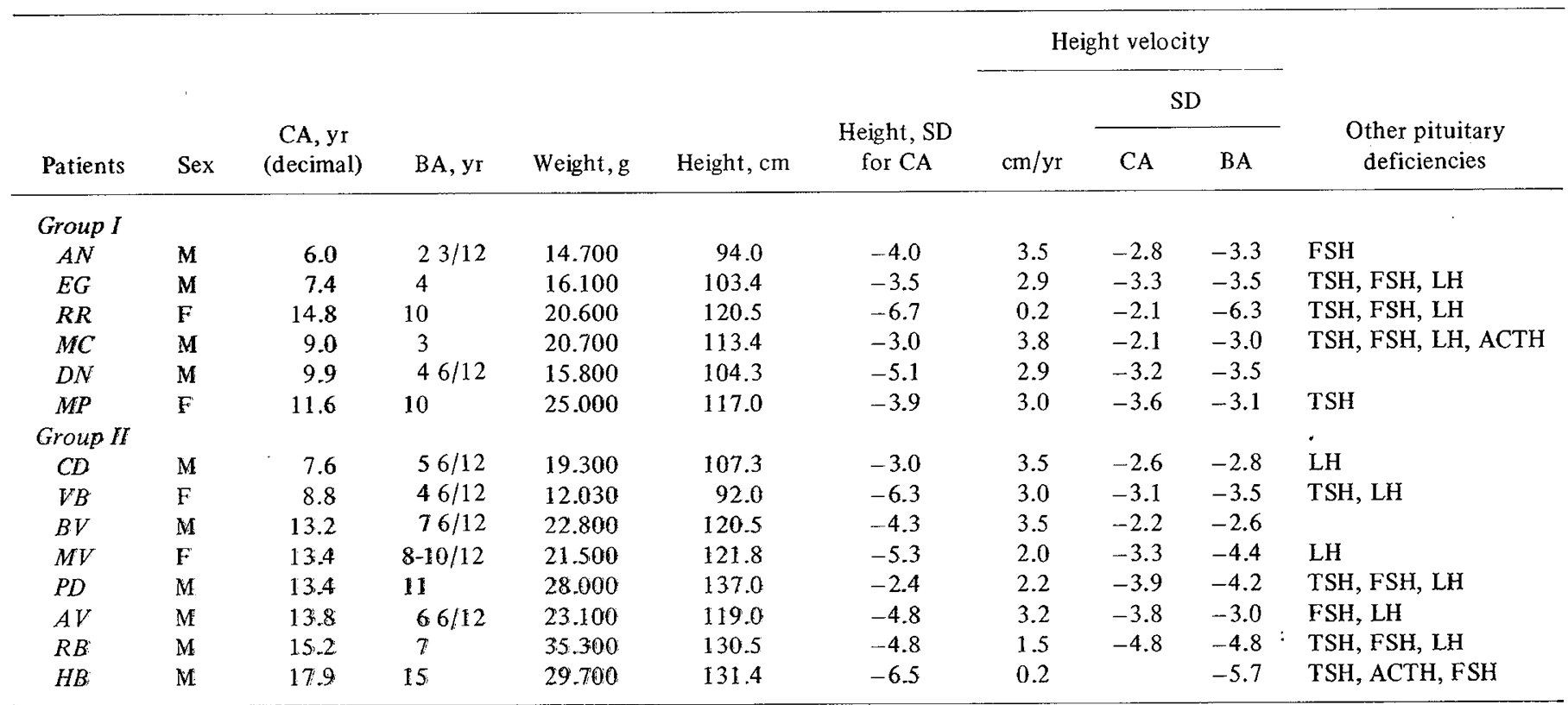

'CA: chronologic age; BA: bone age; M: male; F: female; FSH: follicle-stimulating hormone; TSH: thyroid-stimulating hormone; LH: luteinizing hormone; ACTH: adrenocorticotropic hormone.

Table 2. Results of treatment in six hypopituitary patients

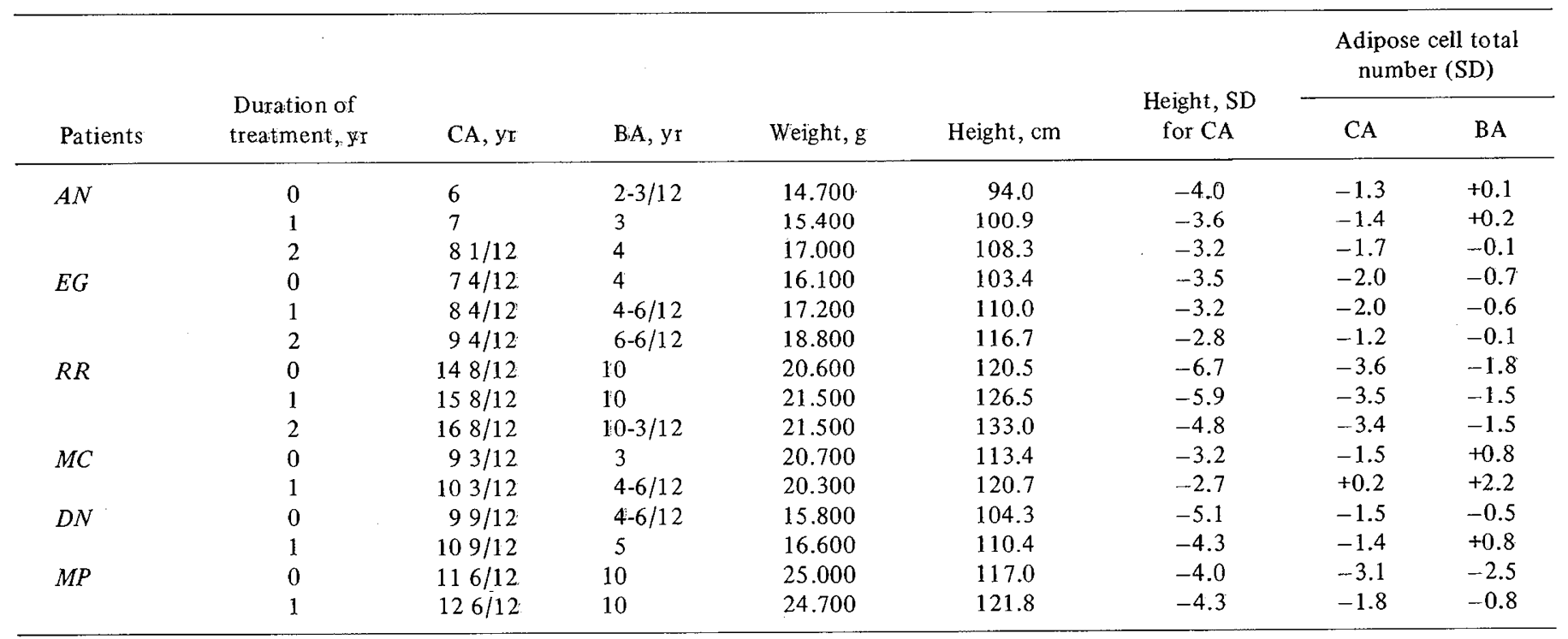

${ }^{1} \mathrm{CA}$ : chronologic age; BA: bone age. 
Methyl esters of the fatty acids extracted by petroleum ether were injected into a gas chromatograph (Varian Aerograph model 2100 (41); detector F.I.D. column, 6 feet, 1/8-inch internal diameter; 12\% DEGS on Anakron ABS 50/60 mesh (42); oven temperature progressively raised from 100 to $130^{\circ}$; injection temperature, $250^{\circ}$, detection temperature, $350^{\circ}$; nitrogen flow, $25 \mathrm{ml} / \mathrm{min}$, hydrogen flow, $25 \mathrm{ml} / \mathrm{min}$ ). The individual fatty acids were identified by comparing their retention time to those of known reference compounds. Negligible amounts of minor components were not taken into account for further calculation.

Skinfold thickness was measured by the Harpenden skinfold caliper at the following sites: biceps, triceps, subscapular area, abdomen, and above the iliac crest (12). The whole body fat was estimated from the tricipital and subscapular skinfold thickness according to the method of Pariskova (25). The total number of adipocytes was calculated from the body fat and the mean adipose cell weight. The results obtained in the hypopituitary patients have been compared with data collected previously in normal children and, when informative, in obese children of the same age (2). Cell number has been related to age. Because it is known that in normal children after 1 year of age adipocyte cell size from the subscapular area remains stable, age was not taken into account (2).

Plasma GH was determined by radioimmunoassay with double antibody technique $(30,43)$.

\section{RESULTS}

\section{BEFORE HGH TREATMENT}

Total Adipose Cell Number. Figure 1 represents the total subcutaneous adipocyte number in hypopituitary patients as related to chronologic age and to bone age. There was a very

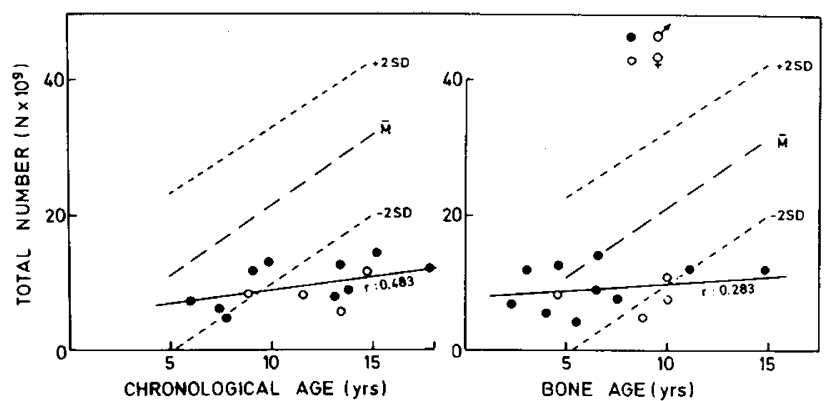

Fig. 1. Total number of adipose cells as a function of chronologic age and bone age in 35 normal children and 14 hypopituitary patients. The regression lines (mean $\pm 2 \mathrm{SD}$ ) of the control values are indicated by -... The individual values of the hypopituitary patients are shown by the $\circ$ and $\bullet$ and their regression line by.$-- T G$ : triglycerides. significant $(P<0.001)$ reduction of adipose cell number according to chronologic age and to skeletal age.

Adipose cell size. Table 3 summarizes the mean diameter and mean cell weight of the adipose cells of 14 hypopituitary patients, of 44 normal children, and of 66 obese children. The average adipose cell size of the hypopituitary patients, although smaller than that of the obese subjects, was significantly larger than that of the control subjects.

Figure 2 represents the relation between subcutaneous adipose cell mean weight and tricipital and subscapular skinfold thickness in the hypopituitary patients compared with the mean of $\pm 2 \mathrm{SD}$ observed in normal children. A significant correlation, similar to that observed in normal children, was seen.

Fatty Acids Distribution in Subcutaneous Fat and in Lipids in Blood. In Table 4, the distribution of individual fatty acids in the adipose tissue triglycerides and of the free fatty acids in blood, triglycerides, phospholipids, and cholesterol esters of the hypopituitary patients is compared with that of normal children. The distribution of fatty acids in the subcutaneous fat was similar in both groups of children and the small differences observed in the blood lipid composition are, with a single exception $\left(C_{18: 2}\right)$, not significant.

\section{AFTER HGH TREATMENT}

Total Adipose Cell Number. As shown in Figure 3A, total adipose cell number in relation to bone age increases rapidly in all cases except one subject $(A N)$ during the 1st year of $\mathrm{HGH}$ treatment. As shown in Table 2, this is also apparent from the changes in SD of total adipose cell number. During the 2 nd

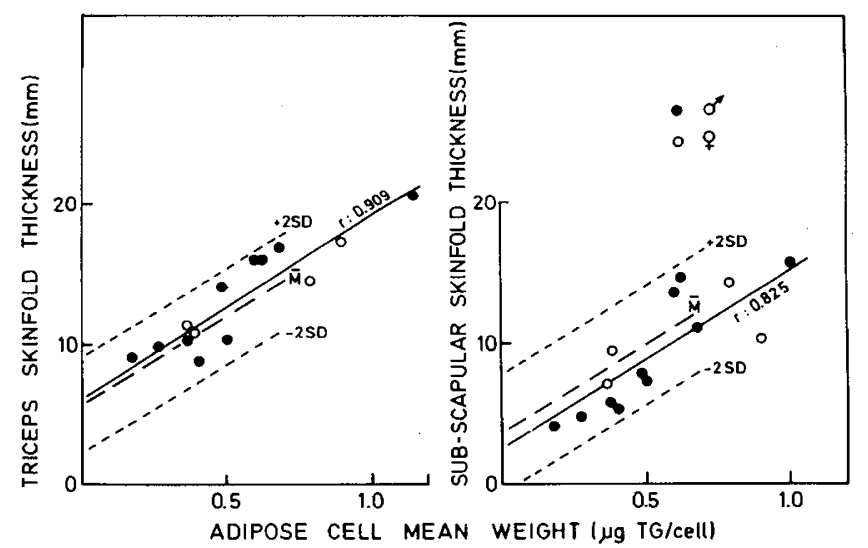

Fig. 2. Relation between subcutaneous adipose cell mean weight and triceps or subscapular skinfold thickness. The regression lines (mean \pm 2 SD) of the control values are indicated by -... The individual values for hypopituitary patients are shown by the $\circ$ and $\bullet$ and their regression line by.$-- T G$ : trigly cerides.

Table 3. Adipose cell size characteristics (mean $\pm S D$ ) of hypopituitary patients compared with those of normal and of obese children

\begin{tabular}{|c|c|c|c|c|c|}
\hline & $\begin{array}{l}\text { Hypopituitary } \\
\text { patients }\end{array}$ & $\begin{array}{c}\text { Normal } \\
\text { children }^{1}\end{array}$ & $P$ value & $\begin{array}{c}\text { Obese } \\
\text { children }^{2}\end{array}$ & $P$ value \\
\hline Average cell diameter $(\mu)$ & $100 \pm 15.4$ & $82 \pm 12$ & $<0.001$ & $118 \pm 12$ & $<0.001$ \\
\hline $\begin{array}{l}\text { Average cell wt ( } \mu \mathrm{g} \text { trigly- } \\
\text { cerides/cell) }\end{array}$ & $0.557 \pm 0.256$ & $0.283 \pm 0.110$ & $<0.01$ & $0.813 \pm 0.257$ & $<0.001$ \\
\hline Average variance $\left(s^{2}\right)^{3}$ & $442 \pm 228$ & $275 \pm 149$ & $<0.001$ & $751 \pm 259$ & $<0.01$ \\
\hline
\end{tabular}

\footnotetext{
${ }^{1}$ Forty-four children of normal weight 2-14 years of age.

${ }^{2}$ Sixty-six obese children $2-17$ years of age.

${ }^{3}$ Average variance $\left(\mathrm{s}^{2}\right)$ calculated from the variance of the individual cell size distribution curve obtained in each subject by measuring 200 adipose cells.
} 
Table 4. Distribution (percentage) of the fatty acids (mean $\pm S D$ ) in adipose tissue triglycerides and in free fatty acids (FFA) in blood, triglycerides, phospholipids, and cholesterol esters of hypopituitary patients and of normal children

\begin{tabular}{|c|c|c|c|c|c|c|c|c|c|c|}
\hline \multirow[b]{2}{*}{ Fatty acids } & \multicolumn{2}{|c|}{$\begin{array}{l}\text { Adipose tissue } \\
\text { triglycerides }\end{array}$} & \multicolumn{2}{|c|}{ FFA in blood } & \multicolumn{2}{|c|}{ Triglycerides in blood } & \multicolumn{2}{|c|}{ Phospholipids in blood } & \multicolumn{2}{|c|}{$\begin{array}{l}\text { Cholesterol esters } \\
\text { in blood }\end{array}$} \\
\hline & Controls ${ }^{1}$ & Patients & Controls $^{2}$ & Patients & Controls $^{2}$ & Patients & Controls $^{2}$ & Patients & Controls $^{2}$ & Patients \\
\hline $\mathrm{C}_{12: 0}$ & $2.2 \pm 2.2$ & $1.3 \pm 1.7$ & & & & & & & & \\
\hline$C_{14: 0}$ & $4.9 \pm 1.1$ & $4.6 \pm 1.4$ & & & & & & & & \\
\hline$C_{16: 0}$ & $21.3 \pm 2.5$ & $22.0 \pm 2.1$ & $29.5 \pm 5.2$ & $28.3 \pm 3.7$ & $30.1 \pm 4.8$ & $27.8 \pm 2.9$ & $31.6 \pm 3.9$ & $30.6 \pm 3.8$ & $11.8 \pm 1.7$ & $12.5 \pm 2.4$ \\
\hline$C_{18: 0}$ & $7.6 \pm 1.6$ & $7.3 \pm 1.8$ & $11.6 \pm 2.4$ & $11.3 \pm 3.3$ & $3.1 \pm 1.2$ & $3.4 \pm 1.4$ & $15.9 \pm 1.6$ & $15.7 \pm 2.1$ & Traces & Traces \\
\hline$C_{18: 1}$ & $42.4 \pm 2.4$ & $42.0 \pm 3.4$ & $35.4 \pm 5.5$ & $39.7 \pm 4.4$ & $46.3 \pm 4.0$ & $43.0 \pm 3.4$ & $15.1 \pm 2.9$ & $13.9 \pm 1.5$ & $22.1 \pm 4.3$ & $16.9 \pm 3.2$ \\
\hline $\mathrm{C}_{18: 2}$ & $12.8 \pm 4.0$ & $14.6 \pm 5.2$ & $11.7 \pm 3.7$ & $14.9 \pm 3.0$ & $15.1 \pm 3.7$ & $22.4 \pm 3.5^{3}$ & $22.4 \pm 3.0$ & $27.4 \pm 4.1$ & $56.0 \pm 5.8$ & $64.0 \pm 4.1$ \\
\hline $\mathrm{C}_{20: 4}$ & Traces & Traces & $2.4 \pm 1.8$ & $2.1 \pm 1.4$ & $1.4 \pm 1.5$ & $1.6 \pm 0.5$ & $9.7 \pm 2.4$ & $9.8 \pm 1.8$ & $6.2 \pm 1.7$ & $5.5 \pm 1.2$ \\
\hline Total unsaturated & 63.5 & 64.0 & 58.7 & 58.0 & 66.7 & 68.6 & 51.9 & 53.6 & 87.8 & 87.4 \\
\hline Total saturated & 36.0 & 35.3 & 41.1 & 39.6 & 33.1 & 31.2 & 47.5 & 46.3 & 12.1 & 12.5 \\
\hline
\end{tabular}

${ }^{1}$ Twenty-five normal children $1-15$ years of age.

${ }^{2}$ Forty-two normal children $1-15$ years of age.

${ }^{3}$ Differences of controls vs. hypopituitary patients: $P<0.05$.
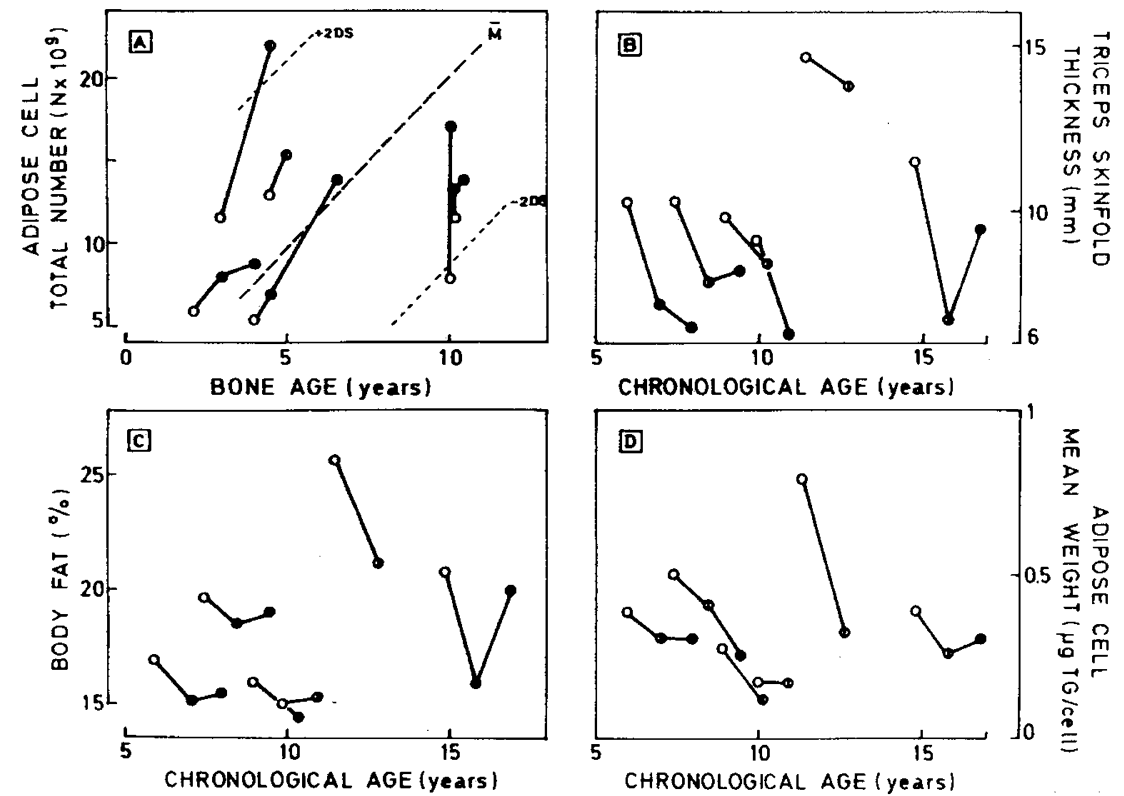

Fig. 3. Total number of adipose cells as a function of bone age and triceps skinfold thickness, adipose cell mean weight, and body fat as a function of chronologic age and duration of human growth hormone treatment in six hypopituitary patients. Each patient is shown individually before (०) and after $1(\odot)$ or $2(\bullet)$ years of treatment. $T G$ : triglycerides.

year of treatment this increase is maintained in patient $E G$, whereas, in the two remaining cases, it is less marked.

Skinfold Thickness and Adipose Cell Size. As shown in Table 5 and in Figure $3 B$, skinfold thickness is decreased very significantly after the 1 st year of treatment with HGH. The body fat mass calculated from the triceps and the subscapular skinfolds is reduced (Fig. $3 C$ ). There is also a very significant reduction of the average adipose cell weight (Fig. $3 D$ ).

The effects of $\mathrm{HGH}$ after a 2nd year of treatment could only be studied in three cases: as shown in Figure 3, skinfold thickness has now increased in two out of three cases. The decrease of cell mean weight has leveled off in one case and is replaced by a rise in another one.

Fatty Acids Distribution in Subcutaneous Fat and in Lipids in Blood. The distribution of fatty acids in the subcutaneous fat triglycerides before and after 1 year of HGH treatment is shown in Table 6. A significant reduction of the unsaturated fatty acids at the $5 \%$ level was observed. After the 2 nd year of HGH administration, no further changes were seen in the three cases studied. The lipid composition in blood did not change significantly after either 1 or 2 years of HGH treatment.

\section{DISCUSSION}

Our data confirm that, as shown by Brook $(7,8)$, the number of subcutaneous adipose cells is abnormally low in hypopituitarism. This abnormality is most striking when adipocyte number is related to chronologic age and bone age. Cell replication in adipose tissue apparently needs the presence of growth hormone. On the other hand, the average adipose cell size of the patients is larger than normal and is closely related to their tricipital skinfold thickness. The fat accumula- 
Table 5. Modifications of skinfold thickness, fatty body mass, and mean adipose cell weight (mean $\pm S D$ ) observed after 1 year of human growth hormone ( $\mathrm{HGH})$ treatment in six hypopituitary patients

\begin{tabular}{lccc}
\hline & $\begin{array}{c}\text { Before HGH } \\
\text { treatment }\end{array}$ & $\begin{array}{c}\text { After 1 year } \\
\text { of HGH }\end{array}$ & $P$ value \\
\hline $\begin{array}{c}\text { Triceps skinfold thickness } \\
\text { (mm) }\end{array}$ & $10.8 \pm 1.5$ & $8.3 \pm 2.7$ & $<0.001$ \\
$\begin{array}{c}\text { Subscapular skinfold } \\
\text { thickness (mm) }\end{array}$ & $7.2 \pm 3.7$ & $5.3 \pm 1.6$ & $<0.001$ \\
$\begin{array}{c}\text { Fatty body mass (\% whole } \\
\text { body weight) }\end{array}$ & $19.1 \pm 4.0$ & $16.9 \pm 2.7$ & $<0.001$ \\
$\begin{array}{c}\text { Average fat cell weight } \\
(\mu \mathrm{g} \text { triglycerides/cell) }\end{array}$ & $0.419 \pm 0.204$ & $0.269 \pm 0.103$ & $<0.001$ \\
\hline
\end{tabular}

${ }^{1}$ Paired $t$ test.

Table 6. Distribution (percentage) of fatty acids (mean $\pm S D$ ) in adipose tissue triglycerides after 1 year of $H G H$ treatment in hypopituitary patients

\begin{tabular}{lrc}
\hline \multicolumn{1}{c}{ Fatty acids } & $\begin{array}{c}\text { Before } \\
\text { treatment }\end{array}$ & $\begin{array}{c}\text { After 1 year } \\
\text { of treatment }\end{array}$ \\
\hline $\mathrm{C}_{12: 0}$ & $1.0 \pm 0.6$ & $1.3 \pm 0.5$ \\
$\mathrm{C}_{14: 0}$ & $3.8 \pm 1.3$ & $4.7 \pm 0.9$ \\
$\mathrm{C}_{16: 0}$ & $20.5 \pm 1.0$ & $21.8 \pm 1.3$ \\
$\mathrm{C}_{16: 1}$ & $5.3 \pm 0.8$ & $3.0 \pm 2.8$ \\
$\mathrm{C}_{18: 0}$ & $7.6 \pm 1.6$ & $11.0 \pm 2.3^{1}$ \\
$\mathrm{C}_{18: 1}$ & $41.7 \pm 5.2$ & $41.1 \pm 2.1$ \\
$\mathrm{C}_{18: 2}$ & $15.0 \pm 6.2$ & $13.3 \pm 4.5$ \\
Total unsaturated & $65.9 \pm 3.4$ & $59.7 \pm 3.2^{1}$ \\
Total saturated & $33.5 \pm 2.6$ & $38.8 \pm 4.0^{1}$ \\
\hline
\end{tabular}

${ }^{1}$ Differences between values obtained before and after 1 year of HGH treatment, $P<0.05$.

tion observed in some hypopituitary patients is of the hypertrophic type exclusively and not of the hyperplastic type. This differs from what is commonly observed in childhood obesity (2).

HGH treatment in hypopituitary patients is associated with a very significant decrease in the adipocyte cell size together with an increase in cell number. The net result is a significant decrease in skinfold thickness, as already shown by several authors $(27,33)$. It is clear that lipolysis induced by exogeneous $\mathrm{GH}$ supersedes the effect of $\mathrm{GH}$ on adipocyte replication. In five out of six patients the increase in total number of adipose cells during the 1st year of treatment exceeded that observed during normal growth. This was contrary to the recent study of Brook (8), who found no increased multiplication rate after 6 months of treatment. This contradiction might be explained tentatively by the longer duration of treatment for our patients, and/or by the difference in site where subcutaneous adipose tissue biopsy was performed (11). In the briefly reported study of Knittle et al. (22) on adipose tissue cellularity in six cases of ateliotic dwarfism, the response to exogeneous HGH was more diverse than in our cases. Of the six patients treated for 8 months, only two showed an increase in number of adipose cells together with a decrease in cell size. In three subjects the number of adipose cells increased without changes in cell size. In only one subject was an increase in cell size observed. Knittle et al. (22) found different modifications in glucose tolerance before and after treatment and propose a link between the changes in glucose metabolism and adipocyte response after $\mathrm{HGH}$ in hypopituitarism. Our own material does not allow us to elaborate further on this matter. If catch-up growth does occur, one would have to admit that adipose tissue organogenesis is not limited to a finite period ending after the 1st year of life. However, it must be stressed that the estimation of total number of adipocyte cells is, at best, a very rough method.

Acute lipolysis induced by several agents including $\mathrm{HGH}$ is associated with a rise in the proportion of unsaturated fatty acids in free fatty acids in blood $(3,10,20,21,37,38)$. It is still unclear whether this is caused by a higher rate of peripheral utilization and, concomitantly, an accelerated mobilization of the unsaturated fatty acids from the fat stores or, conversely, by a lower rate of peripheral utilization. In all our patients the proportion of unsaturated fatty acid in the adipose tissue was decreased after the 1st year of treatment without changes in the blood composition. This shows that, at least after lipolysis induced by repeated administration to exogenous $\mathrm{HGH}$, it is the unsaturated fraction which is used peripherally.

\section{SUMMARY}

Subcutaneous fat and blood lipids were studied in 14 prepubertal children with idiopathic hypopituitarism. The investigations were repeated in six cases after 1 year and in three cases after 2 years of treatment with HGH.

Total number subcutaneous adipose cells in patients with hypopituitarism was significantly lower than in normal children. The administration of $\mathrm{HGH}$ induced a decrease in adipocyte size and an increase in cell number.

Before treatment, the distribution of individual fatty acids in the subcutaneous fat triglycerides and in the blood lipids did not differ from that of the normal children. After 1 year of $\mathrm{HGH}$ treatment, the fatty acids unsaturated fraction was decreased in the adipose tissue triglycerides, whereas it remained unchanged in the blood. No further modifications were observed after the 2 nd year of treatment.

\section{REFERENCES AND NOTES}

1. Aceto, T., Frasier, D., Hayles, A. B., Meyer-Bahlburg, H. F. L., Parker, M. L., Munschauer, R., and Di Chiro, G.: Collaborative study of the effects of human growth hormone in growth hormone deficiency. J. Clin. Endocrinol. Metab., 35: 483 (1972).

2. Bonnet, F.: Contribution à l'étude de l'obésité de l'enfant. Ph.D. thesis, Presses Universitaires de Liège, 1973.

3. Bonnet, F., Gosselin, L., Chantraine, J., and Senterre, J.: Free fatty acid pattern in the plasma of normal and obese children during fasting and intravenous glucose tolerance test. Arch. Int. Physiol. Biochem., 78: 495 (1970).

4. Bonnet, F., Gasselin, L., Chantraine, J., and Senterre, J.: Fatty acid composition of plasma lipids in normal and obese children under fasting conditions and during an intravenous glucose tolerance test. Rev. Eur. Etud. Clin. Biol., 15: 976 (1970).

5. Bonnet, F., Gosselin, L. Senterre, J., and Chantraine, J. Subcutaneous adipose cell size and number in children. Rev. Eur. Etud. Clin. Biol., 15: 1101 (1970).

6. Bonnet, F., Gosselin, L., Chantraine, J., and Senterre, J.: Subcutaneous adipose cell size and number in normal and obese children. Proceedings of the 13th International Congress of Pediatrics, Vienna, Vol. 7, p. 231, 1971

7. Brook, C. G. D.: Evidence for a sensitive period in adipose cell replication in man. Lancet, ii: 624 (1972).

8. Brook, C. G. D.: Effect of human growth hormone treatment on adipose tissue in children. Arch. Dis. Childhood, 48: 725 (1973)

9. Cheek, D. B.: Cellular growth, hormones, nutrition and time. Pediatrics, 41: 30 (1968).

10. Descomps, B., Jean, R., Astruc, M., and Crastes de Paulet, A.: The composition of the non-esterified fatty acids in the plasma of children. Mobilization by noradrenaline drip. Pathol. Biol., 17 : 721 (1969).

11. Duckerts, M., and Bonnet, F.: Adipose cell size differences related to the site of adipose tissue biopsy in children. Biomedicine (Paris), 19: 214 (1973).

12. Edwards, D. A. W., Hammond, W. H. Healy, M. J. R., Tanner, J. M., and Whitehouse, R. H.: Design and accuracy of calipers for measuring subcutaneous tissue thickness. Brit. J. Nutr., 9: 133 (1955). 
13. Ferrandez, A., Zachmann, M., Prader, A., and Illig, R.: Isolated growth hormone deficiency in prepubertal children: Influence of human growth hormone on longitudinal growth, adipose tissue, bone mass and bone maturation. Helv. Paediat. Acta, 25: 566 (1970).

14. Folch, J., Lees, M., and Stanley, G. H. S.: A simple method for the isolation and purification of total lipids from animal tissues. $J$. Biol. Chem., 226: 497 (1957).

15. Goldrick, R. B.: Morphological changes in the adipocyte during fat deposition and mobilization. Amer. J. Physiol., 212: 277 (1967).

16. Greulich, W. W., and Pyle, S. I.: Radiographic Atlas of Skeletal Development of the Hand and Wrist, Ed. 2 (Stanford University Press, Stanford, Calif., 1959).

17. Hirsch, J., and Gallian, E.: Methods for the determination of adipose cell size in man and animals. J. Lipid Res., 9: 110 (1968).

18. Hooft, C., and Casneuf, J.: Familial hypopituitary dwarfism. Helv. Paediat. Acta, 6: 653 (1966).

19. Job, J. C., Garnier, P. E., Chaussain, J. L., Binet, E., Rivaille, P., and Milhaud, G.: Effects of synthet ic luteinizing hormone-releasing hormone (LH-RH) on serum gonadotropins ( $\mathrm{LH}$ and $\mathrm{FSH}$ ) in normal children and adults. Rev. Eur. Etud. Clin. Biol., 17: 411 (1972).

20. Jurand, J., and Oliver, M. F.: Effect of thyroid activity on fatty acid composition of serum lipids. Atherosclerosis, 11: 125 (1970).

21. Jurand, L., and Oliver, M. F.: Effect of human growth hormone on fatty acid composition of serum lipids. Atherosclerosis, 1l: 141 (1970).

22. Knittle, J. L., Sussman, L., Collip, P. J., and Gertner, M.: The effect of treatment with human growth hormone on glucose tolerance and adipose tissue cellularity in ateliotic dwarfism (Abstract). Diabetes, 21 (suppl. 21): 366 (1972).

23. Matvaux, P., and Beckers, C.: Serum thyrotrophin response to thyrotrophin-releasing hormone in normal children and in patients with short stature and various endocrine or genetic diseases. Clin. Endocrinol., 2: 219 (1973).

24. Merimee, T. J., Lillicrap, D. A., and Rabinowitz, D.: Effect of arginine on serum levels of human growth hormone. Lancet, $i i$ : 668 (1965).

25. Pariskova, J.: Total body fat and skinfold thickness in children. Metabolism, 10: 794 (1961).

26. Prader, A., Ferrandez, A., Zachmann, M., and Illig, R.: Effect of HGH treatment on growth, bone age and skinfold thickness in 44 children with growth hormone deficiency. In: Growth and Growth Hormone, International Congress Series, No. 244, p. 452 (Exerpta Medica, Amsterdam, 1972).

27. Prader, A., Zachmann, M., Poley, J. R., Illig, R., and Szeky, J.: long-term treatment with human growth hormone (Raben) in small doses: Evaluation of 18 hypopituitary patients. Helv. Paediat. Acta, 22: 423 (1967)

28. Raben, M. S. : Preparation of growth hormone from pituitaries of man and monkey. Science, 125: 883 (1957).

29. Roth, J., Glick, S. M., Yalow, R. S., and Berson, S. A.: Hypoglycemia: A potent stimulus to secretion of growth hormone. Science. :40: 987 (1963).

30. Schalach, D. S., an Parker, M. L.: A sensitive double antibody immunoassay for 1 . an growth hormone in plasma. Nature 203: 1141 (1964).

31. Tanner, J. M., Goldstein, H., and Whitehouse, R. H.: Standards for

Copyright $\odot 1974$ International Pediatric Research Foundation, Inc. children's height at ages 2-9 years allowing for height of parents. Arch. Dis. Childhood, 45: 755 (1970).

32. Tanner, J. M., and Whitehouse, R. H.: The effect of human growth hormone on subcutaneous fat thickness in hyposomatotrophic and panhypopituitary dwarfs. J. Endocrinol., 39: 263 (1967).

33. Tanner, J. M., Whitehouse, R. H., Hughes, P. C. R., and Vince, F P.: The effect of human growth hormone treatment on the growth of 100 children with growth hormone deficiency, low birth weight, inherited smallness, Turner Syndrome, and other complaints. Arch. Dis. Childhood, 46: 745 (1971).

34. Tanner, J. M., Whitehouse, R. H., and Takaishi, M.: Standards from birth to maturity for height, weight, height velocity and weight velocity: British children, 1965. Part I. Arch. Dis. Childhood, 41: 454 (1966); Part II. Arch. Dis。Childhood, 41: 613 (1966).

35. Thomas, K., Malvaux, P., and Ferin, J.: LH and FSH releasing potency of the synthetic decapeptide p, Glu-His-Trp-Ser-Tyr-GlyLeu-Arg-Pro-Gly-NH $\mathrm{N}_{2}$ in normal prepuberal males. J. Clin. Endocrinol. Metab., 35: 938 (1972).

36. Vanderschueren-Lodeweyckx, M., Wolter, R., Malvaux, P., Eggermont, E., and Eeckels, R.: Hormonal responses to the administration of glucagon in children. In: Proceedings of the European Society for Paediatric Endoctinology, Bergen, p. 42, 1973.

37. Warembourg, H., Biserte, G., Jaillard, J., Sezille, G., and Bertrand, M.: Variations qualitatives et quantitatives des acides gras non estérifiés du plasma humain sous l'effet de perfusions intraveineuses d hormone adrénocorticotrope. Pathol. Biol., 16: 609 (1968).

38. Wood, P., Schlierf, G., and Kinsell, L.: Plasma free oleic and palmitic acid levels during vigorous exercise. Metabolism, 14 : 1095 (1965).

39. Zurbrügg, R., P., and Joss, E. E.: Diagnostic procedures in hypopituitary dwarfism. II. Evaluation of ACTH deficiency: Metopirone test, the daily oscillation of plasma cortisol and its response to exogenous ACTH, lysin-vasopressin, insulin-induced hypoglycemia and general anesthesia. Helv. Paediat. Acta, 4: 382 (1970).

40. Thyrotropin-releasing hormone was obtained from Hoffmann-La Roche Laboratories, Belgium, and LH-RH from Hoechst Laboratories, Germany.

41. Model 2100, Varian Aerograph, Walnut Creek, Calif

42. Analabs, Inc., Ashland, Mass.

43. Highly purified human growth hormone (HS 1394) was kindly supplied by Dr. A. E. Wilhelmi through the courtesy of the National Institute of Arthritis and Metabolic Diseases, Bethesda, Md., guinea pig antihuman growth hormone serum was donated by Dr. R. Bouillon, Department of Internal Medicine, Katholieke Universiteit, Leuven, Belgium.

44. The technical assistance of Miss M. R. Daune and Mrs. G. Theatre-Albert is gratefully acknowledged.

45. Dr. M. Vanderschueren-Lodeweyckx is "aspirant" of the Belgian "Nationaal Fonds voor Geneeskundig Wetenschappelijk Onderzoek."

46. This research was supported in part by Grant no. 20.041 from the Belgian "Nationaal Fonds voor Geneeskundig Wetenschappelijk Onderzoek."

47. Requests for reprints should be addressed to: F. Bonnet, M.D., Clinique et Policlinique des Maladies de l'Enfance, Hôpital de Bavière, Liège, Belgium.

48. Accepted for publication May 6, 1974. 